\title{
HIGH RESOLUTION MAGNETOSTRATIGRAPHY OF CARIBBEAN PLIO-PLEISTOCENE DEEP-SEA SEDIMENTS
}

\author{
DENNIS V. KENT and DANN J. SPARIOSU \\ Lamont-Doherty Geological Observatory and Department of Geological Sciences of \\ Columbia University, Palisades, NY 10964 (U.S.A.)
}

(Received February 18, 1982)

\section{ABSTRACT}

Kent, D. V. and Spariosu, D. J., 1983. High resolution magnetostratigraphy of Caribbean Plio-Pleistocene deep-sea sediments. Palaeogeogr., Palaeoclimatol,, Palaeoecol., 42: $47-64$.

The ability of the hydraulic piston corer (HPC) to recover virtually undisturbed sections of semi-consolidated deep-sea sediments suitable for paleomagnetic study was first demonstrated on Leg 64 and Leg 68 of the Glomar Challenger. Reported here is a complete magnetostratigraphy for a $150 \mathrm{~m}$ section of Plio-Pleistocene pelagic deposits recovered at Site 502 in the Caribbean. Correlation of the magnetic polarity zones to the well-dated standard sequence of geomagnetic polarity reversals provides a precise geochronological framework for age-calibration of calcareous plankton fossil datums and which, combined with the moderate to high sedimentation rates $(24-38 \mathrm{~m} / \mathrm{m} . \mathrm{y}$.), present an opportunity to study paleoenvironmental variations in the Early Pleistocene and the Pliocene with a time control and resolution heretofore possible only in Late Pleistocene deep-sea sediment cores.

\section{INTRODUCTION}

Since the discovery in the 1960's that the record of geomagnetic polarity reversals is preserved in deep-sea sediments (Harrison and Funnell, 1964; Opdyke et al., 1966), magnetostratigraphic correlation has developed as a standard dating method for Neogene sediments. Correlation of the observed polarity succession to the age-calibrated standard sequence of geomagnetic polarity reversals has provided age estimates for important Late Miocene to Late Pleistocene fossil datums (Hays and Opdyke, 1967; Hays et al., 1969; Gartner, 1973; Saito et al., 1975), for the boundaries of the PliocenePleistocene (Glass et al., 1967; Berggren et al., 1967; Haq et al., 1977) and the Miocene-Pliocene (Ryan et al., 1974; Saito et al., 1975), and for various paleooceanographic and paleoclimatic phenomena recorded in the sediments (Shackleton and Opdyke, 1973, 1976, 1977; Keigwin and Shackleton, 1980). Recently, the application of magnetostratigraphic techniques to terrestrial deposits is contributing to the geochronology of Neogene vertebrate fossil zonations worldwide (Johnson et al., 1975; Opdyke et al., 1977, 1979). 
The geomagnetic field has reversed its polarity at widely variable and randomly distributed intervals. The only property that distinguishes polarity zones from each other is their relative duration in a sequence. The longer and more continuous the sequence, the more likely that a pattern of polarity intervals characteristic of some portion of the geomagnetic polarity time-scale will be identified with some confidence. In practice, other information of geochronological significance is used to narrow the search.

The principal source material for magnetostratigraphic-biostratigraphic correlation in the Late Neogene is the conventional piston core of deep-sea sediments. The practical limitation of conventional piston cores to about $30 \mathrm{~m}$ in length imposes a constraint on either the temporal resolution or duration represented by the recovered section. Thus, either an expanded, high resolution section of relatively young sediment or a compressed, low resolution section presenting a long time interval is obtained. In some circumstances it is possible to either extend the stratigraphy back in time or to obtain expanded portions of certain older intervals if hiatuses have removed an intervening portion of the column. One must wonder though if undetected hiatuses are also present in the recovered section which would add uncertainty to the identification of polarity zones as well as to the fossil ranges.

Rotary drill coring overcomes limitations to the length of sections but the recovered cores of semi-consolidated Neogene sediments typically show extensive drilling disturbance. Few successful magnetostratigraphic studies on this disrupted material have therefore emerged. Sediment mixing from drilling disturbance also degrades the resolution of biostratigraphic information.

These problems have now been largely resolved with the innovation of the hydraulic piston corer (HPC). This technique combines the generally undisturbed nature of conventional piston cores with the great depth penetration possible with a drill string. The ability to recover long, relatively undisturbed sections of Late Neogene sediments, suitable for detailed magneto-biostratigraphic study, was demonstrated in the first extensive use of the HPC device on Leg 68. We report here the successful first attempt to obtain a magnetic reversal stratigraphy on HPC material, at Site 502 in the Caribbean.

\section{Lithological and biostratigraphic setting}

Site 502 is located at $11.5^{\circ} \mathrm{N}$ lat., $79.3^{\circ} \mathrm{W}$ long., in the Venezuela Basin of the Caribbean. A virtually complete sequence, a total of $229 \mathrm{~m}$ thick, of Upper Miocene to Recent sediments was recovered in four adjacent, stratigraphically overlapping holes. The sediment consists of foram-bearing nanno marl which grades to calcareous and ash-bearing clay with depth. The section can be divided into four lithostratigraphic subunits, from the top: (1) forambearing nanno marl $(0-7 \mathrm{~m}) ;(2)$ foram-bearing nanno marl with nannobearing marl $(7-110 \mathrm{~m}) ;(3)$ similar but grading to calcareous clay and ash 
and pyrite-bearing clay $(110-210 \mathrm{~m}) ;(4)$ calcareous and ash bearing clay distinguished by the first appearance of siliceous microfossils.

Volcanic ash layers occur sporadically in the upper $110 \mathrm{~m}$ but increase in frequency down section until they constitute a dominant component near the base of the section. Several of the ash layers in the upper $150 \mathrm{~m}$ of section are sufficiently distinctive to be reliable lithostratigraphic marker beds, to confirm precise hole to hole correlation.

Siliceous microfossils occur only in the top few meters and then not again until the base of the recovered section at Site 502. Biostratigraphic dating of sediment was therefore largely based on planktonic foraminifera and calcareous nannofossil datums (see Prell et al., 1980, for summary). Noteworthy foram datums identified are the first appearance (FAD) of Globorotalia truncatulinoides to define the Pliocene-Pleistocene boundary at $51 \mathrm{~m}$, last appearance (LAD) of Sphaeroideinellopis for the Early-Late Pliocene boundary $(81 \mathrm{~m})$ and the FAD of Globorotalia margaritae to define the Miocene-Pliocene boundary at about $146 \mathrm{~m}$. These levels were supported to within a few meters by the nannofossil datums e.g., Discoaster broweri FAD (Plio/Pleistocene) and Ceratolithus acutus FAD (Mio/Pliocene).

Deeper at Site 502, the Amaurolithus primus FAD at $195 \mathrm{~m}$ provides a datum which has been assigned an age of $6.25 \mathrm{Ma}$ (Haq et al., 1980). The base of the section is lowermost Upper Miocene: Radiolaria characteristic of the Ommtartus antepenultimus zone were found below $211 \mathrm{~m}$.

\section{Analytical procedure}

A description of the HPC technique can be found in Prell et al. (1980). A full core is nominally $4.5 \mathrm{~m}$ long but shorter lengths are obtained when the coring device does not extend fully in more cohesive sediments deeper in the section. After retrieval, each core is cut into sections of the standard $1.5 \mathrm{~m}$ length or less, starting at the top. The relative orientation of each section within a core was preserved; however, attempts to obtain core to core azimuthal orientations were not successful. Immediately after routine handling and labelling, the core sections were delivered whole to the paleomagnetic laboratory onboard Challenger for measurement on a long-core spinner magnetometer. The cores were then split and sampled for various purposes in the normal routine.

The long-core spinner magnetometer onboard the ship is a commercially available, computer interfaced instrument similar to that described by Molyneux (1971). A core section is spun at approximately $7 \mathrm{~Hz}$ and the component of the natural remanent magnetization (NRM) in the horizontal plane (perpendicular to the core axis) is measured at successive levels. Each measurement usually was an integration over $2^{6}$ spins and took approximately $10 \mathrm{sec}$. The noise level of the magnetometer $\left(2 \times 10^{-5}\right.$ total moment c.g.s.) was typically well below the sediment magnetization readings (greater than $1 \times 10^{-4}$ total moment c.g.s.) so that instrument sensitivity was not an 
important limiting factor in obtaining a reliable record. The sensor geometry gives magnetization measurements integrated over several centimeters of core length but readings taken at $10 \mathrm{~cm}$, the nominal stratigraphic interval used, are essentially independent. The sensor response function combined with the diameter of the cores indicates that the effective volume of sediment contributing to a measurement is approximately $150 \mathrm{cc}$.

Although rapidly and easily obtained, the long-core measurements do not give information on the vertical component of magnetization nor can the stability of the sediment magnetizations be adequately assessed. Consequently, we also investigated the total magnetization of discrete samples, at least one from each core section after splitting, by measurement on a conventional sample spinner magnetometer. The sample magnetization declinations are referred to the same orientation line as the long-core measurements; the remanent inclinations are calculated with the usual assumption that the drill core axis is vertical. Together with progressive alternating field demagnetization experiments, the discrete sample data provide a check on the validity and reliability of the long-core measurements and aid in the interpretation of a characteristic magnetostratigraphic record.

Diagrams illustrating AF demagnetization behavior of a few representative samples are shown in Fig.1. In sample $16 \mathrm{~A}-3,22 \mathrm{~cm}$ the demagnetization trajectory proceeds directly toward the origin from the NRM, that is the magnetization directions are essentially the same before and after demagnetization and there is only a progressive decrease in remanent intensity with higher demagnetization levels. The inclination is positive and in this case conforms to the expected dipole value of about $+22^{\circ}$ for the site latitude; thus the sample records a normal polarity. Sample $16 \mathrm{C}-2,109 \mathrm{~cm}$ shows an initial trajectory away from the origin. With demagnetization to higher fields, the more stable component of magnetization has a shallow, negative inclination. The sample NRM is therefore interpreted to record a reversed polarity with a small normal polarity overprint of presumed viscous origin.

The determination of polarity based on inclination becomes increasingly more difficult with depth in section, particularly below about $130 \mathrm{~m}$, due to nearly horizontal magnetizations. Demagnetization data show that the very shallow inclinations are a characteristic feature of these samples, carried over a broad spectrum of coercivities (e.g., $46 \mathrm{~A}-1,41 \mathrm{~cm}$ and $63 \mathrm{~A}-1,88 \mathrm{~cm}$ ). We suspect that in situ sediment compaction may be responsible for the progressive shallowing of the magnetization directions. A unique opportunity to test this hypothesis is at hand with these virtually undisturbed sediment cores since the measured physical properties which are more likely here to be representative of in situ conditions than in rotary drilled sediment, can be directly compared to changes in sediment magnetic properties.

It is nevertheless clear from these analyses of discrete sample magnetizations that the long-core measurements of the horizontal component of NRM alone are generally representative of the stable direction of magnetization of the sediment. Low coercivity magnetizations of secondary origin are typically 


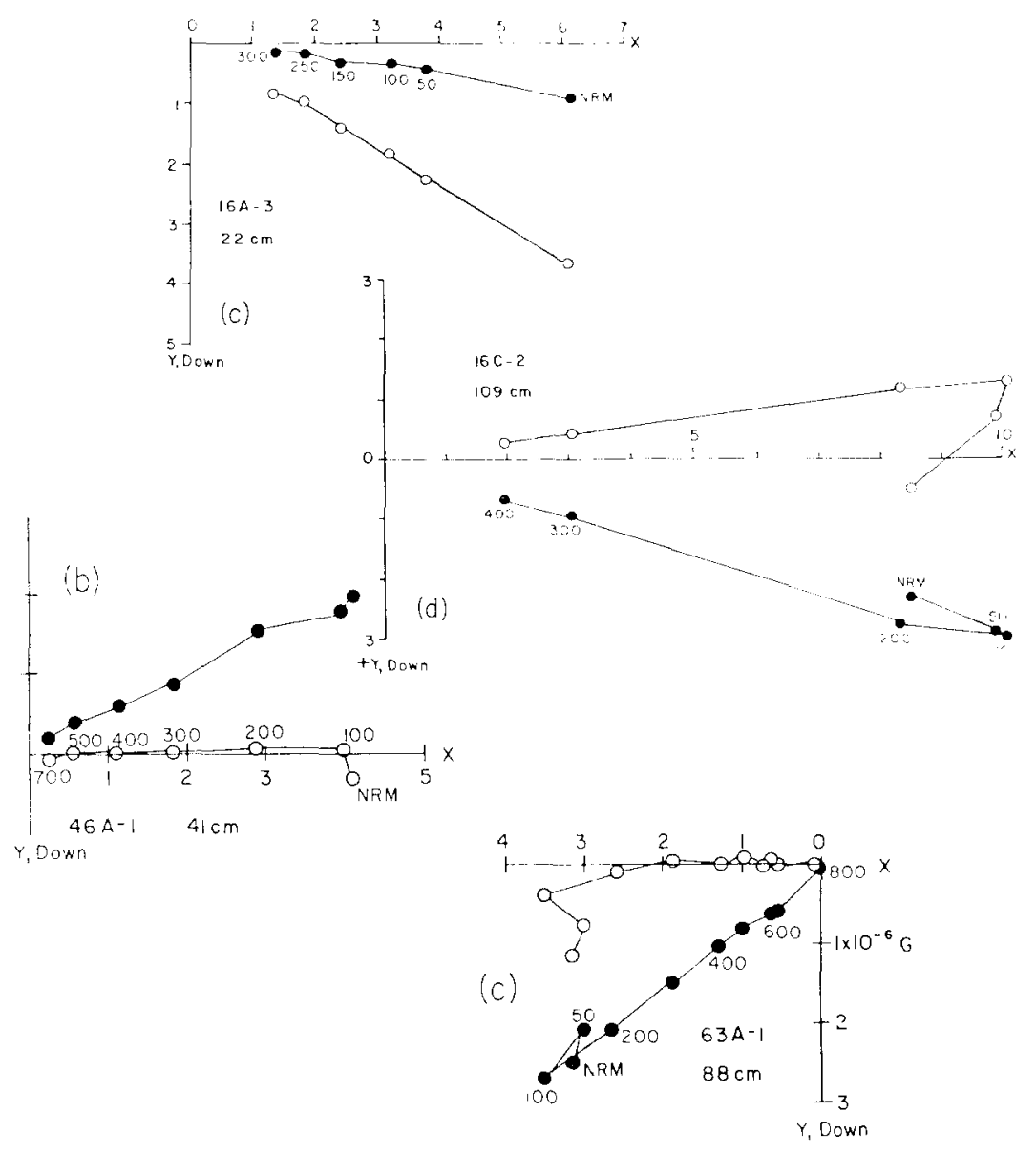

Fig.1. Representative vector end-point diagrams of progressive AF demagnetization of NRM of samples from Site 502. Solid (open) circles are projections of remanent vector end-point on horizontal (vertical) plane. Orientation of horizontal $X$ axis is arbitrary between samples from different cores. Magnetization units on axes in $10^{-6} \mathrm{G}\left(10^{-3} \mathrm{~A} \mathrm{~m}^{-1}\right)$. Numbers adjacent to end-point symbols are AF demagnetization levels in Oe $\left(10^{-1} \mathrm{mT}\right)$.

small and do not appreciably deflect the NRM away from the orientation of the stable component, particularly since they are also generally aligned along the same axis. Due to the low latitude of the site, reversals in magnetization polarity are most readily seen as $180^{\circ}$ shifts in declination within a core. The closely spaced long-core measurements can thus be used to locate magnetization reversal levels rapidly and with good precision. The inclinations obtained from the less numerous discrete sample measurements help to resolve the polarity ambiguity in these azimuthally unoriented cores but only in about the upper half of the recovered section. In the lower half of the section, the discrete sample measurements gave little additional information than already obtained from the whole core measurements because the inclinations lie 
virtually in the horizontal. The shallow inclinations contributed to our inability to establish the sense of magnetic polarity below about $145 \mathrm{~m}$.

\section{Composite magnetic polarity log}

The levels of reversals of magnetization polarity detected at each of the holes at Site 502 are shown in Table I. The magnetization reversals levels listed are those which occur at $180^{\circ}$ shifts in declination within individual cores and do not include magnetization reversals that are suspected to occur between cores. In all cases, the $180^{\circ}$ shifts in declination from the long-core

\section{TABLE I}

Subbottom depths $(\mathrm{m})$ to magnetozone boundaries identified in four holes at Site 502 ; age of correlative chrons in Ma modified from Mankinen and Dalrymple (1979)

\begin{tabular}{|c|c|c|c|c|c|}
\hline $\begin{array}{l}\text { Magnetozone } \\
\text { boundary }\end{array}$ & Age & 502 & $502 \mathrm{~A}$ & $502 \mathrm{~B}$ & $502 \mathrm{C}$ \\
\hline Brunhes/Matuyama & 0.73 & - & $17.1-17.3$ & $15.3-15.4$ & - \\
\hline $\begin{array}{l}\text { Jaramillo } \\
\text { top } \\
\text { bottom }\end{array}$ & $\begin{array}{l}0.91 \\
0.98\end{array}$ & $\begin{array}{l}19.1-19.5 \\
20.5-20.8\end{array}$ & $\begin{array}{l}20.3-20.4 \\
22.2-22.3\end{array}$ & $\overline{21.3}-21.6$ & $\begin{array}{l}- \\
-\end{array}$ \\
\hline $\begin{array}{l}\text { Olduvai } \\
\text { top } \\
\text { bottom }\end{array}$ & $\begin{array}{l}1.66 \\
1.88\end{array}$ & $\begin{array}{l}37.9-38.1 \\
-\end{array}$ & $\begin{array}{l}39.6-39.8 \\
46.8-46.9\end{array}$ & $\overline{42.2-42.4}$ & - \\
\hline Matuyama/Gauss & 2.48 & $60.1-60.3$ & - & - & $55.5-55.7$ \\
\hline $\begin{array}{l}\text { Kaena } \\
\text { top } \\
\text { bottom }\end{array}$ & $\begin{array}{l}2.92 \\
2.99\end{array}$ & - & $\begin{array}{l}78.1-78.2 \\
79.6-79.9\end{array}$ & $\begin{array}{l}73.5-73.8 \\
75.4-75.5\end{array}$ & $\begin{array}{l}67.3-67.5 \\
70.1-70.4\end{array}$ \\
\hline $\begin{array}{l}\text { Mammoth } \\
\text { top } \\
\text { bottom }\end{array}$ & $\begin{array}{l}3.08 \\
3.18\end{array}$ & $\begin{array}{l}80.5-80.7 \\
82.5-82.7\end{array}$ & $\begin{array}{l}83.4-83.5 \\
-\end{array}$ & $\begin{array}{l}79.1-79.3 \\
-\end{array}$ & $\begin{array}{l}73.7-74.1 \\
-\end{array}$ \\
\hline Gauss/Gilbert & 3.40 & $89.3-89.6$ & $91.7-92.1$ & - & - \\
\hline $\begin{array}{l}\text { Cochiti } \\
\text { top } \\
\text { bottom }\end{array}$ & $\begin{array}{l}3.86 \\
3.95\end{array}$ & $\begin{array}{l}105.3-105.4 \\
108.9-109.1\end{array}$ & - & - & $\begin{array}{l}100.9-101.2 \\
104.8-105.0\end{array}$ \\
\hline $\begin{array}{l}\text { Nunivak } \\
\text { top } \\
\text { bottom }\end{array}$ & $\begin{array}{l}4.08 \\
4.21\end{array}$ & $\overline{-}$ & $\begin{array}{l}117.0-117.2 \\
120.3-120.5\end{array}$ & $\overline{-}$ & $\begin{array}{l}109.5-109.6 \\
112.5-112.7\end{array}$ \\
\hline $\begin{array}{l}\mathrm{C}_{1} \\
\text { top } \\
\text { bottom }\end{array}$ & $\begin{array}{l}4.35 \\
4.43\end{array}$ & $\overline{124.8-125.0}$ & $\begin{array}{l}- \\
-\end{array}$ & $\begin{array}{l}- \\
-\end{array}$ & $\begin{array}{l}117.8-118.0 \\
121.1-121.7\end{array}$ \\
\hline $\begin{array}{l}\mathrm{C}_{2} \\
\text { top } \\
\text { bottom }\end{array}$ & $\begin{array}{l}4.52 \\
4.71\end{array}$ & $128.0-128.2$ & $\begin{array}{c}- \\
135.2-135.3\end{array}$ & - & $\begin{array}{l}- \\
-\end{array}$ \\
\hline
\end{tabular}


measurements have been verified by individual sample measurements as representative of the stable component of magnetization. In many cases, particularly in the upper $120 \mathrm{~m}$ of section, the sense of the polarity change, either from normal to reversed or reversed to normal, can be reasonably determined from nearby sample inclinations and the behavior of the NRMs during progressive AF demagnetization. The determination of polarity is more problematical between $120 \mathrm{~m}$ and $145 \mathrm{~m}$ and we relied more heavily on the consistency of inferred polarities between holes and the overall consistency of the composite magnetic polarity $\log$ at the site with the known record of geomagnetic reversals in the time interval constrained by biostratigraphic information. By these methods it was possible to construct a composite magnetostratigraphy for Site 502 to a depth of approximately $145 \mathrm{~m}$, near to the level of the Miocene-Pliocene boundary. Although a few polarity reversals were detected below this level, we have not yet found it possible to interpret the polarity stratigraphy because of the ambiguity of samples with shallow inclinations and because of gaps in the magnetic record caused by poorer recovery and sediment deformation during coring.

Assuming that a complete section of Plio-Pleistocene sediments is present at Site 502, as indicated by the biostratigraphy, it is possible to correlate the stratigraphic sequence of magnetozones with the known record of magnetochrons in this time interval. Although the interpretation of magnetozones within each hole is to some extent dependent on the integration of paleomagnetic data from all four holes, we in retrospect indicate in Table I the likely correlation of magnetozone with magnetic chron and subchron boundaries for convenience of discussion.

In presenting a composite magnetostratigraphy diagram for Site 502 (Fig. 2), we uniformly adjusted the measured declination directions within each entire core by setting their mean to either $0^{\circ}$ or $180^{\circ}$, according to our interpretation of the polarity, normal or reversed. We emphasize that because of the absence of reliable relative azimuthal orientation of the cores and because of the difficulty in resolving the polarity within many cores from the sample inclination values, particularly at deeper levels in the section, the interpretation of polarity in any core may not be unique. For this reason we delimit the core intervals in Fig.2; alternative interpretations of the magnetostratigraphy are possible by simply readjusting the declinations of any core by $180^{\circ}$. However, we have reason to believe that the interpretation we present in Fig. 2 is the most consistent with all the paleomagnetic and biostratigraphic data available.

There are nineteen polarity reversals that define the well-established succession of normal and reversed polarity intervals in the Plio-Pleistocene. Between 6 and 12 of these are recorded within cores as $180^{\circ}$ shifts in declination at any individual hole at Site 502. The remaining polarity transitions we would expect to find in each hole are apparently missing because of either poor data related to core disturbance or lack of core recovery across critical levels in the sediment column. Nevertheless, all nineteen polarity transitions 
are recorded taking the four holes at Site 502 together and most are found in at least two holes (Table I). Identification of the same polarity transitions in two or more adjacent holes is the basis of developing a composite magnetostratigraphy for Site 502, comprised of overlapping segments from various holes for the upper $145 \mathrm{~m}$ of section.

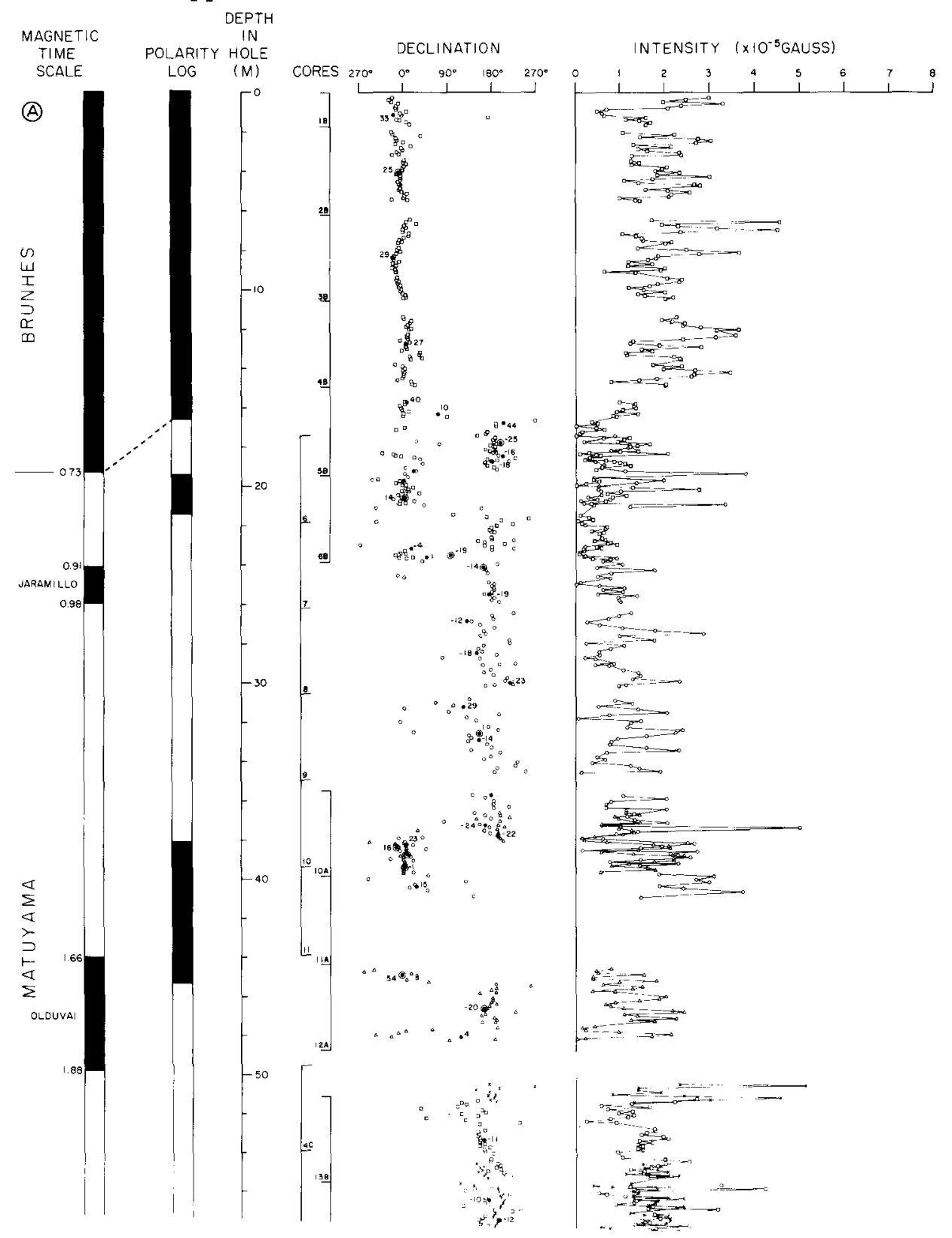

Fig.2A.For legend see p. 57. 


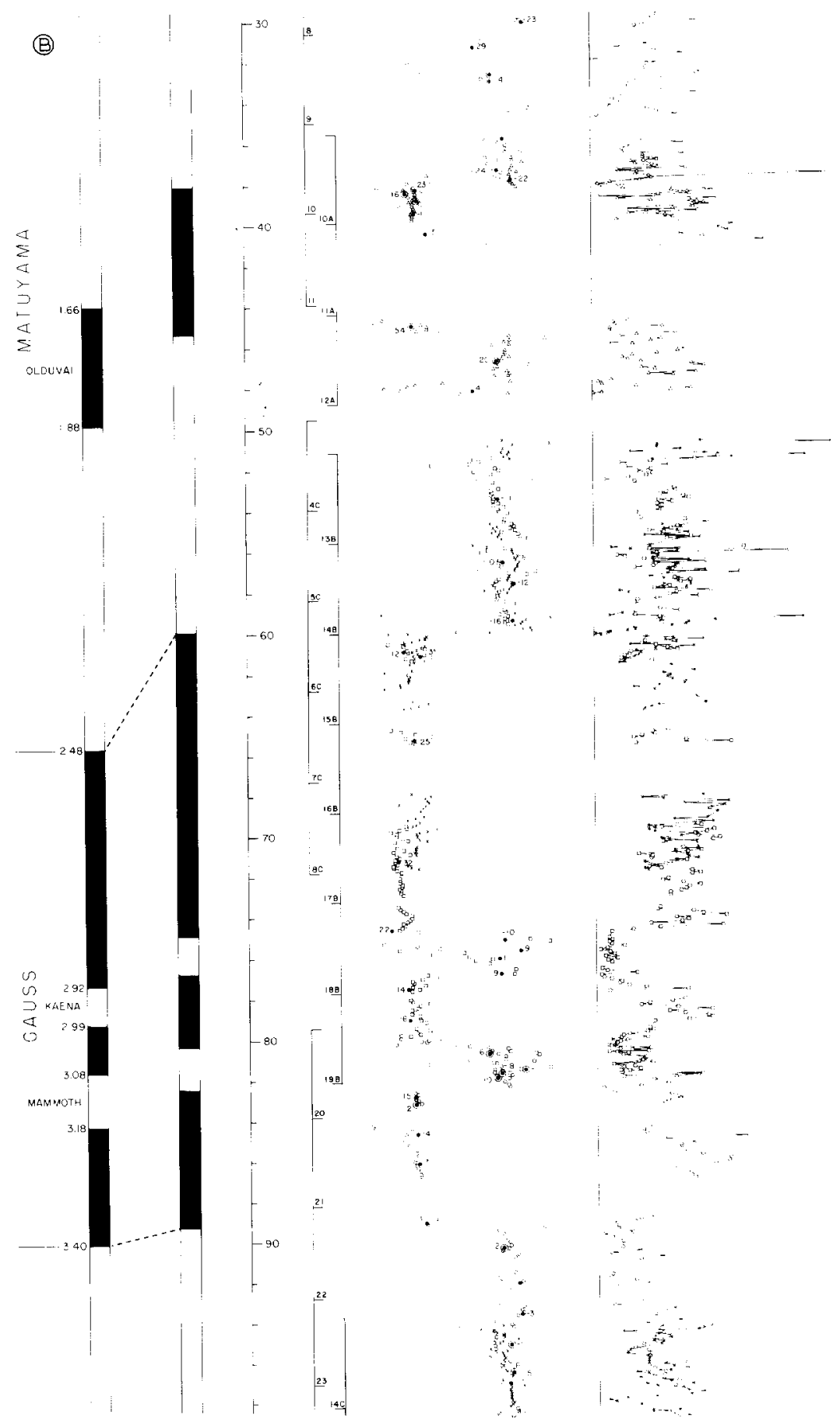

Fig.2B. For legend see p. 57. 


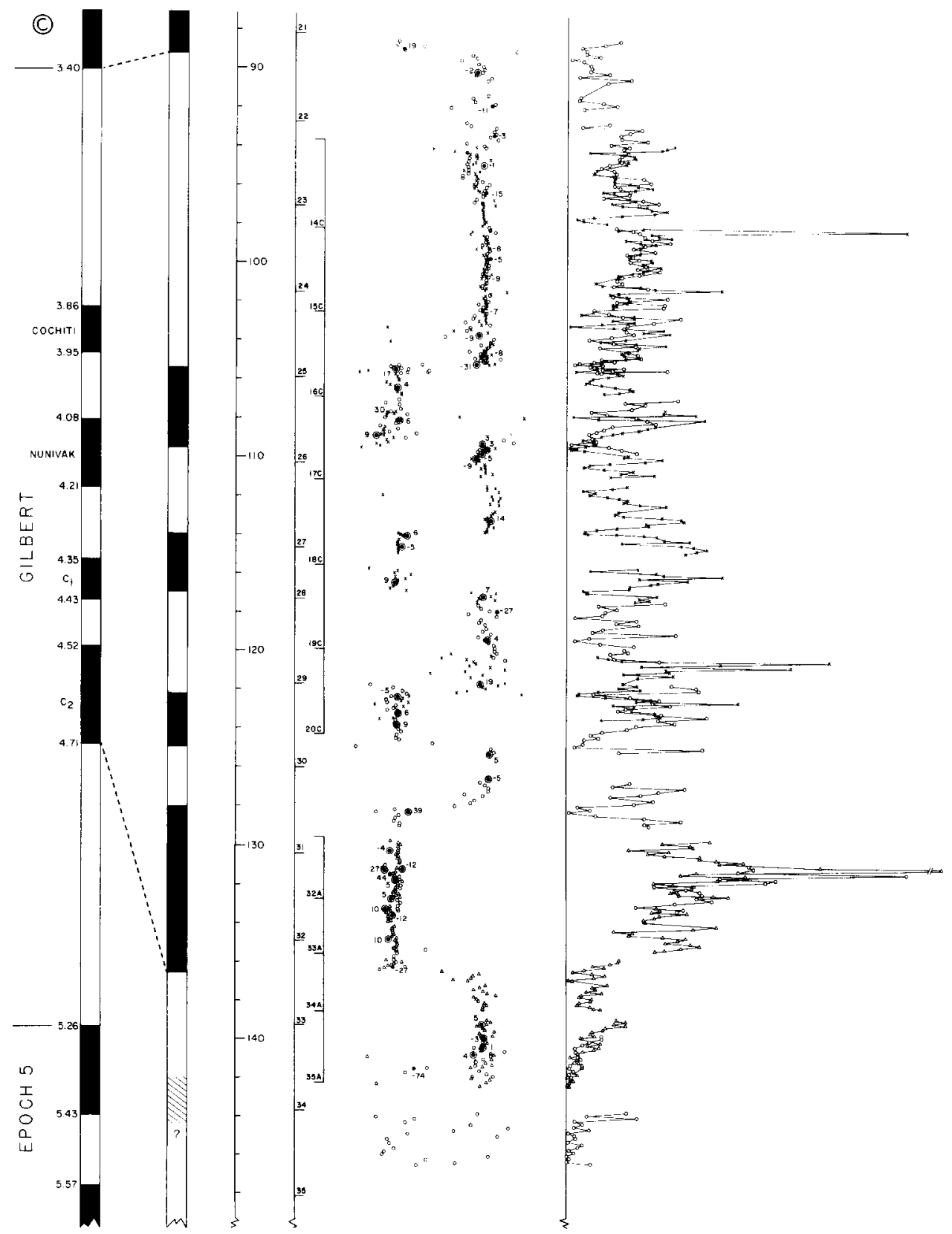

Fig.2C. For legend see p. 57. 
It should be noted that the sub-bottom depths to what we consider to be correlative magnetostratigraphic horizons are often offset by as much as $10 \mathrm{~m}$ among the adjacent holes at Site 502 . We ascribe at least a major portion of these offsets to the rather crude method employed to measure the drill string (with meter stick and chalk mark) and hence the cored intervals, on the ship. Admittedly the problem of inconsistent subbottom depths amongst the individual holes adds another undesired degree of freedom that must be taken into account in establishing a composite magnetostratigraphic section for Site 502. On the other hand, it is unlikely that a complete magnetostratigraphic section could have been developed without multiple holes at the site.

\section{DISCUSSION}

Several features of this composite magnetostratigraphy for the PlioPleistocene sediments at Site 502 are worth mentioning.

Sediments of normal polarity, which we correlate to the Brunhes, extend to about $17 \mathrm{~m}$. The magnetic data are of high internal consistency which attests to the undisturbed quality of core material the HPC is capable of obtaining even in these very unconsolidated sediments at the top of the section.

The predominantly reversely magnetized section between about $17 \mathrm{~m}$ and $60 \mathrm{~m}$, which we correlate to the Matuyama, is punctuated by several zones of normal polarity. The longest of these, between about $19.5 \mathrm{~m}$ and $21.5 \mathrm{~m}$, and between about $38.0 \mathrm{~m}$ and $45.0 \mathrm{~m}$, are correlated to the Jaramillo and Olduvai, respectively, which are the prominent normal polarity intervals typically seen within the Matuyama. The additional, short intervals of normal polarity we observe here within the Matuyama however are less commonly seen. For example, in the vicinity of the Jaramillo there are at least two zones less than $50 \mathrm{~cm}$ thick in which normal magnetizations in a number of adjacent levels are observed, centered at about $18 \mathrm{~m}$ and $24 \mathrm{~m}$.

Fig.2. Composite magnetostratigraphy for four holes at Site 502. Columns from the left: (1) geomagnetic reversal time-scale from LaBrecque et al. (1977) with ages (Ma) corrected after Mankinen and Dalrymple (1979); (2) log of magnetozones and submagnetozones interpreted at Site 502, filled (open) bar indicating predominantly normal (reversed) magnetization polarity; (3) depth in section based largely on Hole 502 ; (4) cores used in assembling composite, suffix (none, $\mathrm{A}, \mathrm{B}, \mathrm{C}$ ) to core number indicating hole $(502,502 \mathrm{~A}$, 502B, 502C); (5) NRM declinations measured with long-core spinner magnetometer on cores from Hole 502 (small open circles), 502A (open triangles), 502B (open squares) and $502 \mathrm{C}$ ( $x$ 's). Filled circles are discrete sample NRM measurements and those encircled are directions after AF demagnetization, both with numbers indicating measured inclination values. The declinations within each core have been uniformly shifted to lie approximately $0^{\circ}-180^{\circ}$ axis, depending on polarity interpretation. Only magnetic measurements from sedimentologically disturbed core intervals are not plotted; (6) remanent intensities measured with long-core magnetometer, assuming a sediment volume of $150 \mathrm{~cm}^{3}$ contributes to signal at each measured level. 
The significance of such features is usually questionable, and they can often be dismissed as some form of magnetization noise since they are not consistently found. Although we cannot be certain that the short normal polarity zones observed here are not due to remagnetization or local sediment disturbance, an interpretation as records of short period geomagnetic reversals or excursions is suggested by their presence at roughly corresponding stratigraphic levels in two holes, and by corroborating demagnetization analyses from discrete samples. We speculate that the short normal magnetozone at $18 \mathrm{~m}$ may record the same paleomagnetic feature described by Watkins (1968) as occurring between the Brunhes and the Jaramillo in several deepsea sediment cores while the normal magnetozone at $24 \mathrm{~m}$, just below the Jaramillo, may be correlative with the Cobb Mt. subchron at $1.1 \mathrm{Ma}$ of Mankinen et al. (1978). The spotty occurrence worldwide of such short polarity intervals may be due to limited geographical extent of the responsible geomagnetic anomaly (Harrison and Ramirez, 1975) or because of poor resolution in the more slowly deposited sediments that are typically studied. High-resolution records from other areas will be needed to resolve the problem.

A complete record of the Olduvai was not obtained because of poor core recovery. Our identification of the top of the Olduvai is fairly unambiguous but the location of the base is somewhat complicated by the presence of short normal polarity intervals that may represent the Reunion subchrons (Gromme and Hay, 1971). For example, the reversal near to the top of core 12A (Fig.2) may just as well represent a feature similar to that observed lower in the same core, rather than the base of the Olduvai as we surmise. The lack of a complete magnetic record in this part of the section is unfortunate because it includes the Plio-Pleistocene boundary.

The section between $60 \mathrm{~m}$ and about $99 \mathrm{~m}$ is predominantly of normal polarity and contains the two reversed intervals, the Kaena and the Mammoth, which are characteristic of the Gauss. The long-core record of the upper reversed interval (Kaena) was noisy which we attribute to a sharply reduced magnetization intensity compounded by larger low coercivity components. Partially demagnetized discrete samples however confirm the presence of stable magnetizations of reversed polarity in this interval. The record of the Mammoth was by contrast unremarkable.

The underlying section of predominantly reversely magnetized sediments is correlated to the Gilbert. We do not see the base of the Gilbert and the polarity transition into Chron 5 . The remanent directions become grossly scattered starting at about $142 \mathrm{~m}$, preceded by a well-marked trend of decreasing remanent intensities from about $138 \mathrm{~m}$ to $142 \mathrm{~m}$.

All four subchrons of the Gilbert reversed chron are apparently recorded although the interpretation of polarity in individual cores is somewhat more tenuous in this part of the section because of shallower inclinations. A major stratigraphic aid in correlating the holes is the very distinctive volcanic ash doublet at approximately $132 \mathrm{~m}$. The top and base of the lower magneto- 
subzone $\left(\mathrm{C}_{2}\right)$ of the Gilbert are recorded in different holes (Table I); our assignment of these magnetization polarity reversals as the limits of the $\mathrm{C}_{2}$ magnetosubzone is largely based on the correlation of the ash doublet between Hole 502 and 502A.

Scattered directions and low remanent intensities persist from $142 \mathrm{~m}$ to approximately $164 \mathrm{~m}$. The cause of the poor record is not clear but we speculate that some lithological change during the latest Miocene (Messinian?) was somehow responsible. The internal consistency of the paleomagnetic data improves below $164 \mathrm{~m}$ to the base of the recovered section but few reversals are detected.

We have not found it possible to interpret polarities with any degree of confidence to any part of the section below $142 \mathrm{~m}$, even utilizing discrete sample measurements.

\section{Sedimentation rates}

A plot of subbottom depths to magnetozones identified at Site 502 with respect to the age of their correlative magnetochrons and subchrons is shown in Fig.3. The slope of the line drawn through the points is a measure of the sedimentation rate for a given interval. The regular nature of the sedimentation rate plot tends to support our interpretation of the magnetostratigraphy of Site 502.

Sedimentation rates generally increase with depth in section, from about $24 \mathrm{~m} / \mathrm{m}$.y. during the Brunhes and Matuyama, $32 \mathrm{~m} / \mathrm{m} . \mathrm{y}$. during the Gauss, and $36 \mathrm{~m} / \mathrm{m} . \mathrm{y}$. in the Gilbert. At the level of resolution of subchrons, sedimentation rates vary from about $17 \mathrm{~m} / \mathrm{m} . \mathrm{y}$., in the reversed interval between the Brunhes and the top of the Jaramillo, to $45 \mathrm{~m} / \mathrm{m}$.y. within subchronozones $\mathrm{C}_{1}$ and $\mathrm{C}_{2}$ of the Gilbert.

The position of the $A$. primus datum $(\simeq 6.25$ m.y.: Haq et al., 1980$)$ at $195 \mathrm{~m}$ indicates that the average sedimentation rate continues to increase slightly, to about $38 \mathrm{~m} / \mathrm{m} . y_{\text {. }}$, in the interval between the base of $\mathrm{C}_{2}(137 \mathrm{~m})$ and that level. The biostratigraphic information also suggests that perhaps as few as four polarity transitions, those defining Chron 5 and subchron A, are expected to occur in the interval $143 \mathrm{~m}$ and $195 \mathrm{~m}$. This could help explain why so few magnetization reversals are detected within cores from this part of the section.

\section{Comparison with other deep-sea sections}

The published inventory of fossiliferous Plio-Pleistocene deep-sea sedimentary sections which have reliable magnetostratigraphic control is surprisingly small and unevenly distributed, considering that the biochronology in this time interval is based largely on correlation to the magnetic reversal time-scale. Fig. 4 shows a comparison of what can be considered to be the best available core records that have been used for direct correlation of 


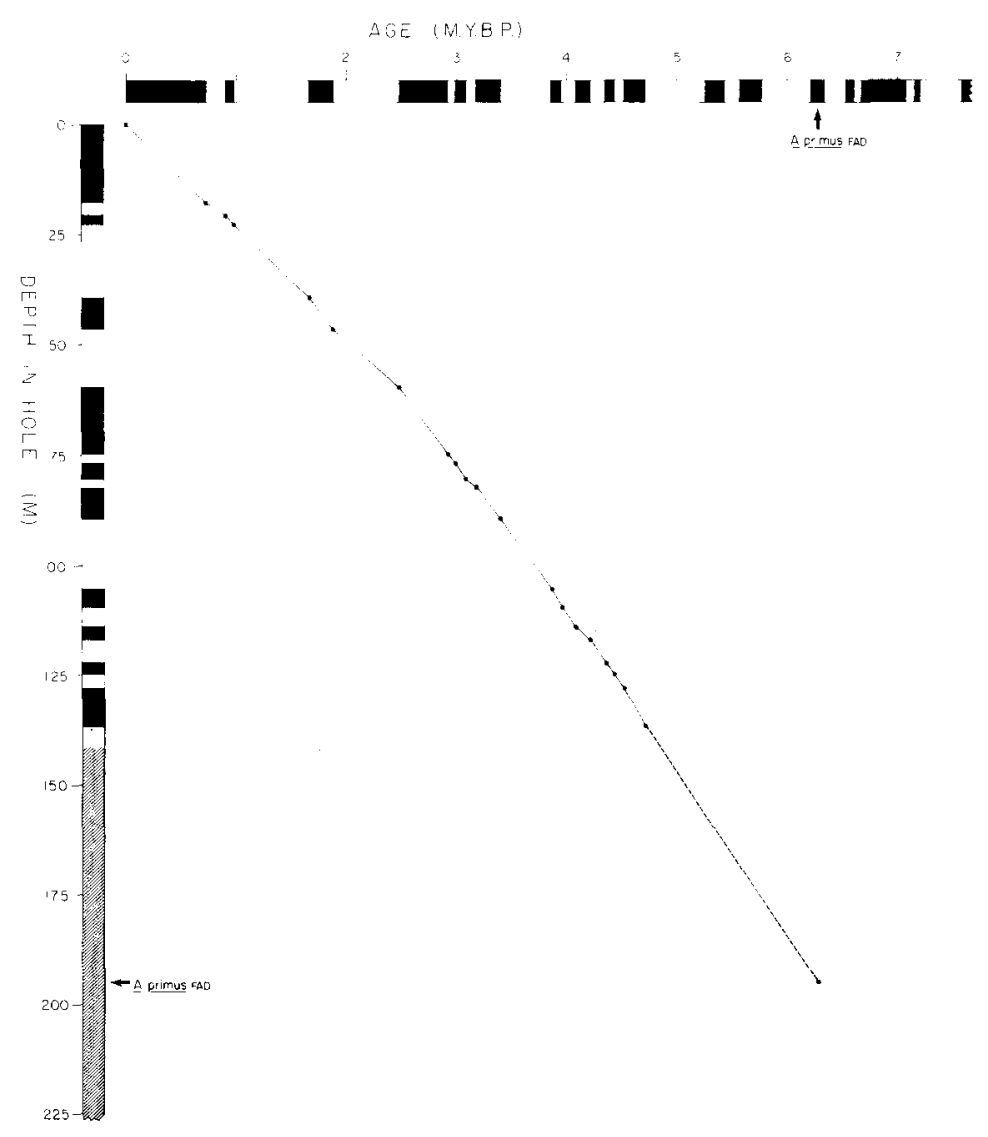

Fig.3. Subbottom depth to magnetozones at Site 502 plotted against the correlative portion of the geomagnetic reversal time-scale of LaBrecque et al. (1977) with corrected ages modified from Mankinen and Dalrymple (1979). Tie point near base of section $(A$. primus $\mathrm{FAD}$ ) based on correlation of biostratigraphic datum to reversal sequence elsewhere (Haq et al., 1980).

calcareous biostratigraphy and magnetostratigraphy, with the section at Site 502.

An obvious feature is that the piston core records are inherently more compressed, and consequently the degree of temporal resolution is reduced, with greater sediment age. The thickness of the Brunhes $(17 \mathrm{~m})$ at Site 502 is not particularly noteworthy and several biostratigraphically useful cores penetrate through the Brunhes/Matuyama boundary at comparable depths, for example, the $12 \mathrm{~m}$ record of the Brunhes in V28-238 provides the principal chronology of Late Pleistocene oxygen isotope stratigraphy (Shackleton and Opdyke, 1973). On the other hand, some of the longest and most complete records of the Matuyama (e.g., V28-239 with $14 \mathrm{~m}$ and V28-179 with $8.3 \mathrm{~m}$ ) and of the Gauss (V28-179 with $4.2 \mathrm{~m}$ ) are 
로익

空怘

可方

要

莒 $>$

茷管

웡이

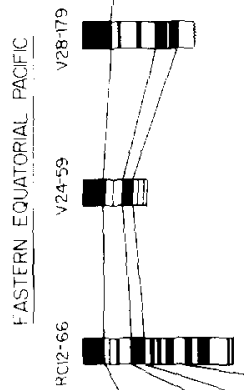

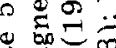

$\stackrel{50}{8}$

एक

$+\infty$

究空 융 象过

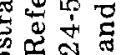
议

क

势落

ह 훙

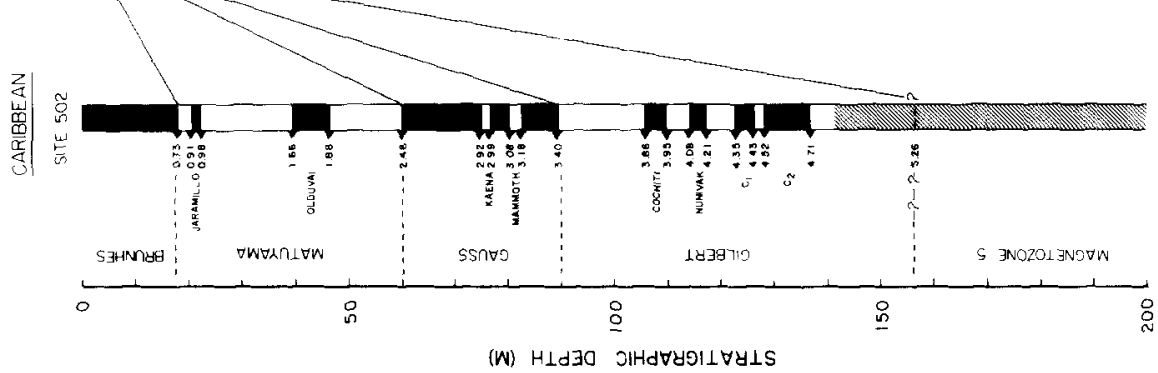

पु

ह

政

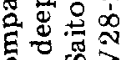
8 w 的 ษ包志去

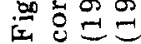


only a small fraction of the length of record available at Site $502(42.5 \mathrm{~m}$ for Matuyama and $29.5 \mathrm{~m}$ for the Gauss). A similar disparity exists for the few records available of the Gilbert, for example, $7 \mathrm{~m}$ in RC12-66 compared with $50 \mathrm{~m}$ at Site 502 .

It is therefore clear that the greatly expanded, well dated Plio-Pleistocene section at Site 502 offers an opportunity to refine the direct calibration of calcareous fossil datums with the paleomagnetic record. Site 502 also complements existing records of the Pliocene which are predominantly from the Pacific. In the Atlantic, there are hardly any piston cores which penetrate even into the Gauss (e.g., V12-18 and V16-205) and the magnetostratigraphically-controlled record at Site 502 will allow more detailed and extended comparisons of Late Neogene sedimentation and biotic history between the two oceans.

But the major advantage of the expanded Plio-Pleistocene section at Site 502 is likely to be the ability to study paleoenvironmental variations recorded in the sediment over this entire time interval with the degree of time resolution and control heretofore possible only in the Late Pleistocene. It should for example thus be possible to characterize the frequency spectrum of Pliocene paleoclimatic variations, as reflected in oxygen isotope fractionation and carbonate contents, to adequately test the applicability of the Milankovich hypothesis of climate change for pre-Late Pleistocene time. Presently, the stratigraphically longest detailed oxygen isotope records from the oceans extend to just below the Olduvai (V28-239: Shackleton and Opdyke, 1976). Although it has been possible to further extend the isotopic record to within the top of the Gilbert (V28-179: Shackleton and Opdyke, 1977), the level of resolution was sufficient only to identify the onset of quasi-cyclic glacial-interglacial fluctuations at about $3 \mathrm{~m} . \mathrm{y}$. while the detailed character of the climatic record is inaccessible in these more slowly accumulated sediments.

\section{ACKNOWLEDGEMENTS}

This work was supported by the National Science Foundation under Grants OCE79-25402 and OCE81-19695. This paper was reviewed by Maureen Steiner, University of Wyoming, Laramie; and Neil Opdyke, University of Florida, Gainesville. LDGO Contribution No. 3431.

\section{REFERENCES}

Berggren, W.A., Phillips, J.D., Bertels, A. and Wall, D., 1967. Late Pliocene-Pleistocene stratigraphy in deep sea cores from the South-central North Atlantic. Nature, 216: $253-255$.

Foster, J. H. and Opdyke, N. D., 1970. Upper Miocene to Recent magnetic stratigraphy in deep-sea sediments. J. Geophys. Res., 75: 4465-4473.

Gartner, S., 1973. Absolute chronology of the Late Neogene calcareous nannofossil succession in the Equatorial Pacific. Geol. Soc. Am. Bull., 84: 2021-2034. 
Glass, B., Ericson, D. B., Heezen, B. C., Opdyke, N. D. and Glass, J. A., 1967. Geomagnetic reversals and Pleistocene chronology. Nature, 216:437-442.

Gromme, C. S. and Hay, R. L., 1971. Geomagnetic polarity epochs: Age and duration of the Olduvai normal polarity event. Earth Planet. Sci. Lett., 10: 179-185.

Haq, B. U., Berggren, W. A. and Van Couvering, J. A., 1977. Corrected age of the Pliocene/Pleistocene boundary. Nature, 269:483-488.

Haq, B. U., et al., 1980. Late Miocene marine carbon-isotopic shift and synchroneity of some phytoplanktonic biostratigraphic events. Geology, 8: 427-431.

Harrison, C. G. A. and Funnell, B. M., 1964. Relationship of paleomagnetic reversals and micropaleontology in two Late Cenozoic cores from the Pacific Ocean. Nature, 204: 566.

Harrison, C. G. A. and Ramirez, E., 1975. Areal coverage of spurious reversals of the Earth's magnetic field. J. Geomagn. Geoelectr., 27: 139-151.

Hays, J. D. and Opdyke, N. D., 1967. Antarctic radiolaria, magnetic reversals and climatic change. Science, 158: 1001-1011.

Hays, J. D., Saito, T., Opdyke, N. D. and Burckle, L. H., 1969. Pliocene-Pleistocene sediments of the equatorial Pacific - Their paleomagnetic, biostratigraphic and climatic record. Geol. Soc. Am. Bull., 80: 1481-1514.

Johnson, N. M., Opdyke, N. D. and Lindsay, E. H., 1975. Magnetic polarity stratigraphy of Pliocene-Pleistocene terrestrial deposits and vertebrate faunas, San Pedro Valley, Arizona. Geol. Soc. Am. Bull., 86: 5-12.

Keigwin Jr., L.D. and Shackleton, N.J., 1980. Uppermost Miocene carbon isotope stratigraphy of a piston core in the equatorial Pacific. Nature, 284: 613-614.

LaBrecque, J. L., Kent, D. V. and Cande, S. C., 1977. Revised Magnetic Polarity Time Scale for the Late Cretaceous and Cenozoic Time. Geology, 5: 330-335.

Mankinen, E.A. and Dalrymple, G.B., 1979. Revised geomagnetic time scale for interval 0-5 m.y. B.P. J. Geophys. Res., 84: 615-626.

Mankinen, E. A., Donnelly, J. M. and Cromme, C. S., 1978. Geomagnetic polarity event recorded at $1.1 \mathrm{~m} . \mathrm{y}$. B.P. on Cobb Mountain, Clear Lake volcanic field, California. Geology, 6: 653-656.

Molyneux, L., 1971. A complete result magnetometer for measuring the remanent magnetization of rocks. Geophys. J. R. Astron. Soc., 10: 429.

Opdyke, N.D., Glass, B., Hays, J.D. and Foster, J., 1966. Paleomagnetic study of Antarctic deep-sea cores. Science, 154: 349-357.

Opdyke, N. D., Lindsay, E. H., Johnson, N. M. and Downs, T., 1977. The paleomagnetism and magnetic polarity stratigraphy of the mammal-bearing section of Anza Borrego State Park, California. Quaternary Res., 7: 316-329.

Opdyke, N. D., Lindsay, E., Johnson, G. D., Johnson, N., Tahirkheli, R. A. K. and Mirza, M. A., 1979. Magnetic polarity stratigraphy and vertebrate paleontology of the Upper Siwalik Subgroup of Northern Pakistan. Palaeogeogr., Palaeoclimatol., Palaeoecol., 27: $1-34$.

Prell, W. L., Gardner, J. V., Adelseck, C., Blechschmidt, G., Fleet, A. J., Keigwin, L. D., Kent, D. V., Ledbetter, M. T., Mann, U., Mayer, L., Reidel, W. R., Sancetta, C., Spariosu, D. J. and Zimmerman, H. B., 1980. Hydraulic piston coring of Late Neogene and Quaternary sections in the Caribbean and equatorial Pacific: Preliminary results of Deep Sea Drilling Project Leg 68. Geol. Soc. Am. Bull., 91:433-444.

Ryan, W. B. F., Cita, M. B., Dreyfus Rawson, M., Burckle, L. H. and Saito, T., 1974. A paleomagnetic assignment of Neogene stage boundaries and the development of isochronous datum planes between the Mediterranean, the Pacific and Indian Oceans in order to investigate the response of the World Ocean to the Mediterranean "Salinity Crisis". Riv. Ital. Paleontol., 80, (4): 631-688.

Saito, T., Burckle, L.H. and Hays, J.D., 1975. Late Miocene to Pleistocene biostratigraphy of equatorial Pacific sediments. In: T. Saito and L.H. Burckle (Editors), Late Neogene Epoch Boundaries. Micropaleontology Press, New York, N.Y, pp. 226-244. 
Shackleton, N.J. and Opdyke, N.D., 1973. Oxygen isotope and paleomagnetic stratigraphy of equatorial Pacific core V28-238: Oxygen isotope temperatures and ice volumes on a $10^{5}$ and $10^{6}$ year scale. Quaternary Res., $3: 39-55$.

Shackletcn, N.J. and Opdyke, N.D., 1976. Oxygen-isotope and paleomagnetic stratigraphy of Pacific core V28-239, Late Pliocene to Latest Pleistocene. Geol. Soc. Am. Mem., 145: 449-464.

Shackleton, N. J. and Opdyke, N. D., 1977. Oxygen isotope and paleomagnetic evidence for early Northern Hemisphere glaciation. Nature, 270: 216-219.

Watkins, N. D., 1968. Short period geomagnetic polarity events in deep-sea sedimentary cores. Earth Planet. Sci. Lett., 4: 341-349. 